\title{
ROMANIAN PRE-UNIVERSITY EDUCATION FINANCING. IDEAL VS. REALITY
}

\author{
Dan T⿱宀ogoe $e^{1}$
}

ABSTRACT: Without a real change, the Romanian education system and especially the preuniversity system will not be able to overcome its instability and provisional character. The reforms that started in 2000 must continue. The success of the decentralization of the pre-university system, as a basic component of the reform, greatly depends on the manner in which the financing of preuniversity education must be carried out in accordance with the number of pupils, and the funds must be assigned to place the pupil in a flexible and facile environment.

Key words: pre-university education reform, financing, decentralization.

JEL codes: H52, H61, H75, H76

\section{Introduction}

Since 2001, Romanian pre-university public education has been funded through the budgets of the local administrative units in area where the schools are located. The aim of this activity is the decentralisation of pre-university education and the connection with the local communities.

The funding system, outlined by the provisions of the current laws and regulations (The Law no. 500/2002 on public finance, the Law no. 273/2006 on the local public finance) presents some limitations, which can generate dysfunctionalities, such as:

- the allocation of funds from the state budget to local budgets cannot take into account the standard costs, and especially the correction indicators while those funds exclusively refer to scholarships and staff expenses;

- the allocation to local councils and schools of salary funds based on standard costs per pupil cannot be made without causing serious dysfunctionalities in the payment of salaries, while the norming and the payroll are established by the law according to teaching ranks and seniority categories teachers;

- the allocation of funds from the state budget to local budgets through the county councils turns the councils into intermediaries, which might make the process of objective distribution of funds more difficult;

- the budget planning through the funding formula derived according to historical costs, is difficult to implement given that the budget project for the following year is substantiated in September, and the necessary data are available only at the end of the year preceding the application of the formula;

- the present system of substantiating budget plans and fund allocation is not sustained by a system of data collection, transmission and processing that should confer objectivity and safety related to the degree of funding of each educational unit and to its real funding needs.

\section{Literature review}

According to the forecasts of the Law of education no. 84/1995, there are two main types of funding for the public pre-university educational units: basic funding (recurrent grant) and extrafunding (supplementary grant).

\footnotetext{
1 “Artifex” University of Bucharest, 47 Economu Cezarescu Street, sector 6, Bucharest, dan_togoe@ @otmail.com
} 
The basic funding allows pre-university education to function according to national standards. The basic funding is ensured through the local budgets of the administrative territorial units to which the schools are assigned. The money comes from some incomes of the state budget and from other incomes of local budgets.

The extra-funding ensures capital expenses, social expenses and other expenses associated with the educational process. The money comes from local budgets and other sources, according to the law.

The basic funding contains the following types of expenditure:

a) staff expenses;

b) material and services expenses;

c) continuing education and training expenses, except the expenses which are covered from the state budget;

d) pupil transport expenses;

e) commuting expenses, the 6 train travels stipulated by the law, for the teachers and support staff;

The extra-funding contains the following types of expenses:

a) consolidations, investments, and capital repairs;

b) stipends for the boarding schools and canteens;

c) expenses for organizing pupil assessments, exam simulations and national examinations, except the expenses covered from the state budget;

d) pupil scholarship expenses;

e) expenses for the mandatory periodical medical examination of the employees from the public pre-university education system, except the free medical examinations as provided by the law;

f) expenses for school competitions and educational, artistic, cultural, sports and tourism activities.

\section{Research methodology}

The basis for the calculation of funds for the basic funding allocated to educational units through and from local budgets is the standard cost per pupil.

The standard cost per pupil is determined, for each education level, branch, profile, specialization/domain, according to the number of available teaching positions/departments legally constituted, to the teaching language, to other indicators specific for education, to the quality of the educational process and professional training, to the institutional management, to the particularities of the training and to the urban/rural environment.

The determination of the standard cost per pupil is made by the National Council for PreUniversity Education Funding, according to the methodological norms elaborated by the Ministry of Education and Research and approved through a Government Decision. The level of the standard cost per pupil is approved by the Ministry of Education and Research, following consultations with social partners and associative structures of public local administration authorities.

The sums representing the basic funding and extra-funding are registered in the budget sheet of income and expenditure of the education unit.

According to the legal provisions, the income and expenditure budget is drawn up annually, by each public pre-university educational unit, according to the methodological norms for preuniversity education funding; it is approved and executed according to the current legal provisions.

The basic funding as reported in the income and expenditure budget of the school is calculated according to the following formula: 


\section{$\mathbf{F}_{\mathrm{b}}=\operatorname{Cs~} \times \sum \mathbf{E}_{\mathrm{i}} \times \mathbf{k}_{\mathrm{i}} \times \mathbf{k}_{\mathrm{rui}}$}

where:

$\mathrm{F}_{\mathrm{b}}=$ the volume of funds for basic funding;

$\mathrm{Cs}=$ the standard cost per pupil in the lower secondary education, urban areas;

$\mathrm{E}_{\mathrm{i}}=$ the number of pupils from the level/profile " $\mathrm{i}$ " of education;

$\mathrm{i}_{1 \ldots . . . \mathrm{n}}=$ the level/profile/branch of education;

$\mathrm{K}_{\mathrm{i}}=$ the coefficient of differentiation according to levels/profiles/branches of education;

$\mathrm{K}_{\text {rui }}=$ the coefficient of differentiation for the urban/rural areas according to the level/profile " $\mathrm{i}$ " of education;

The calculation formula for extra-funding is presented as follows:

$$
\mathbf{F}_{\mathrm{c}}=\sum \mathbf{F}_{\mathrm{c}}
$$

where:

$\mathrm{F}_{\mathrm{c}}=$ the fund related to extra-funding;

$\mathrm{F}_{\mathrm{ci}}=$ the necessary fund for covering the expenses from the field " $\mathrm{i}$ " of activity;

\section{counties}

The conclusions regarding the use of funds in pre-university education from the pilot

An outlook on the funding process initiated in the pilot counties reveals a series of primary conclusions which can be mentioned here:

The allocation of funds by the local councils is not made using objective criteria; the most important criterion is the one of the maximum funding which local councils can get.

Many local councils embraced the idea of adopting clear rules to keep the precise destination of money allocated to education.

There is no objective and safe system for data collection, sending and processing that can be used in the process of fund allocation and in the process of monitoring and reporting. A single and unitary database must be created, based on a single programme and procedure.

The standard cost calculation methodology and the substantiation of the budget requirement according to the formula issued by the National Council for the Financing of Public Pre-University Education were not adopted through a legislative act. Also, the standard cost per pupil was not included in an official act of the Ministry. As a result, this calculation procedure was used randomly or as an experiment.

The schools which do not use the budget simulation methodology use the same old methods of substantiating material expenses, taking into account the consumption of the previous year, corrected with the inflation index. As regards staff expenditure, the aim is to cover the salary fund for the employed staff. The calculations start from necessities and priorities and they try to include as many expense categories as possible, according to the sums allocated by the local council.

Generally, in some schools, a partially unsolved problem is the staffing of financial and accounting departments with specialised staff, professionally trained. The lack of necessary facilities (computers, printers, accounting programmes, payment programmes and legislative), as and the lack of training programmes, causes difficulties for the schools in elaborating the budgets and accounts reports. For this reason, the truthfulness of the data reported by the schools to the Ministry was often questioned.

A problem that affects the good development of the schools' economic activity is the ambiguity of the institutional relations between the local council and the county council on one side, and the school on other side. In a unitary reporting system, these dysfunctions short-circuit the flow 
of information and the results cannot have a sufficient degree of relevance to make the best decisions, irrespective of the level of the deciding factor.

On the other side, the legal framework is characterized by many other problems: normative acts that are not correlated, confusing and difficult to interpret; arbitrary and abusive application; the lack of necessary provisions in the complete application of other measures with a financial character etc.

\section{A short critical analysis and recommendations}

The financial decentralization is an essential pillar in the implementation of the decentralization of pre-university education and the coordination of this process should be accomplished at an institutional level with the clear definition of the assignments and responsibilities in the field.

There still are difficulties in correlating the educational development plans with the local strategic development plans. The dysfunctions are related to the lack of preparation in the field of strategic planning, the lack of a good correlation between the objectives of educational development and the allocated funds and the difficulties in obtaining more funds. The exceptions are the schools involved in projects that are financed from external loans.

The schools have great difficulties in attracting more resources, especially in the rural environment.

Setting a clear connection between the development of the school and the local development would be desirable not only to ensure budgetary coherence but also to ensure the overview coherence of the local development interventions, and also the increasing of the school's and local authorities' public responsibility.

Organising training programmes to ensure the increase of the local capacity to prepare and implement strategic documents of development would be a welcomed idea.

The school principals do not have a constant technical support for management activities, especially for the school's autonomy. Principals should undergo training programmes, especially in the field of financial management. Although there are continuing training programmes available to principals, they are not as many as they should be and very often they lack variety and relevance. Also, the effect of training on the subsequent professional performance of the trained principals was not monitored.

It would be very useful to develop a system that can measure performance and can indicate the effect of the training on performance.

Currently, schools do not have the liberty to change or reassign funds between budgetary titles. Inflexible budgetary rules are still used and the budget is approved by factors considered to be external to the school (the local councils).

It is mandatory to review of the legal framework for local funding in order to make the process of using the funds or their reallocation between budgetary titles more flexible.

The replacement of present budgets with grants (global sums), the decisional right referring to the flexible allocation of the budget which should belong to the Administration Council, the reallocation of unspent funds in accordance with the needs of the school, with the consultation of the local council, would be some of the optimization measures of using the school's funds.

The budget proposed by the schools is not always approved by the local authorities.

The criteria used for approving the budget do not refer to the needs identified through the school's development plan, but to general financial restrictions.

Furthermore, as the local authorities' decision is taken each year, the schools cannot plan several years ahead.

Financial contracts should be signed by the local authorities and the schools so that there is a certainty of the availability of the allocation, along with a real resource basis for the school's development plan. 
Unfortunately, in the current context, the vulnerable point of pre-university funding is connected to the funding formula per capital which could not be used as a result of the lack of a more specific legislation. Therefore, the formula was tested artificially, theoretically, just "on paper". The financial management of schools is still based on "historical" budgets.

Even more imperative would be to continue testing the allocation formula using the database of the schools relating to the present costs per student (already calculated in the pilot schools) which might contribute at the development of the funding formula, based on the standard costs and correction coefficients, in order to implement it.

The legal framework for the schools' financial activity has not allowed piloting the financial decentralization. To implement the decentralization strategy approved through a memorandum of the Romanian Government from December 2005, financial activity included, the financial piloting in the pilot county schools should at least be allowed.

Some schools created a new position to solve financial and budgetary problems. Financial administrators were hired (in accordance with the new regulations and with the pilot project). Of the possible candidates, some did not have the necessary accounting training and had difficulties in adjusting to the administrative and financial system of the school, and others considered the payment unsatisfactory in relation to the work volume.

Therefore, the financial administrators employed in schools should receive budget planning, budget management and budget reporting training.

Outsourcing the schools' financial management services could be taken into consideration; however, even so, the schools should receive specific financial management training, which has a special peculiarity.

The information flow, in our opinion, is insufficient vertically and horizontally, at all levels of the information cycle. The improvement of the information flow between the local, county and national levels will be a support for the motivated staff from the educational system, and the reverse - an international defective flow - will generate frustrations and will constitute a de-motivating factor. The information flow can be improved through constant feedback offered to the schools' reports.

Generally speaking, even if a system of monitoring and evaluation of the educational system exists, there is no system of monitoring and evaluation of the politics and the programmes of the Ministry. Data gathering is usually based on reports. Important data as the one referring to human resources or referring to maintenance expenses of the school are rather incomplete or inexistent.

Schools do not have a public liability system in place. They use public money and as a result, they have the obligation to inform the public about the way they are used. At the same time, the pupils, the parents, the business enterprises etc. want to know how the school works so they can make an informed choice about the children's guidance or their investments.

Also, there is only a sporadic information flow between schools and their clients, between schools and communities, mainly based on personal, informal relations, between the parents and the teachers.

The schools should communicate with the clients (students, parents, local authorities, business enterprises, etc.) in a constant way, since this method is one of the most efficient ways of increasing the quality of education (exposure to beneficiaries). The schools could use the following tools to convey information about the school and its performances: the annual report of the board of trustees, the current public events, the publications already existent in the community. Other methods of practicing public liability are: using the educational development plan as a sustainable instrument of manifesting public liability in the schools, awareness raising of the interested factors regarding the need to increase the schools' competitiveness, thus stimulating their interest in promoting the school and its educational offer, training the members of the board of trustees, and etc. 


\section{References}

1. Boboc I., 2004. Psihosociologia organizaţiilor şcolare şi managementul educaţional, EDP, Bucharest

2. Cojocaru M. V., 2004. Introducere în managementul calității, EDP, Bucharest

3. Cristea, S., 2004. Managementul organizației şcolare, second edition, EDP, Bucharest

4. Dogaru, I., 2002. Formula de finantare a invatamantului preunivesitar din Romania, (Romanian Pre-University Education Financing Formula) Economica Publishing House, Bucharest

5. Iosifescu, Ș., 2001. Managementul educaţional pentru instituţiile de învăţământ. Bucharest

6. Jinga I., 2001. Managementul învățământului, Aldin Publishing House, Bucharest

7. Sălăvăstru, D., 2004. Psihologia educației, Polirom Publishing House, Iaşi.

8. Documents of the National Council for Pre-University Education Funding.

9. Law of education no. 84/1995, re-published in the Official Gazette of Romania, Part 1, issue 606 of 10 December 1999.

10. Ministry of Education and Research - The Pre-University Education Decentralization Strategy.

11. The Romanian legislative framework of the education system functioning and organization, www.edu.ro 